\title{
30 years' membership and a 50th birthday - where to next for ANZASW?
}

\section{David McNabb}

David is a Lecturer at the Department of Social Practice at the Unitec Institute of Technology in Auckland, where he was formerly Head of Department.

\section{Introduction}

This article is a personal reflection on 30 years of membership of the Aotearoa New Zealand Association of Social Workers (ANZASW, and inclusive of the earlier name, the New Zealand Association of Social Workers - NZASW). The major issues and changes faced by ANZASW are considered from the perspective of someone who undertook a range of roles within ANZASW and in the wider profession. Ideas for the future of ANZASW are outlined.

\section{In the beginning}

I grew up in a home that was heavily influenced by the Salvation Army. My parents, Pearce and Winnie McNabb were Officers (ministers) and so my sisters and I all became active in both the Christian church dimension and the social services dimension of the Army. I was imbued with the ethic of service and with the belief that people could change. The alcoholic who was helped out of the gutter could become one of the Officers or other leaders, and I knew people who had come from such beginnings. As I learnt more about the Army I began to appreciate that it also had a track record of addressing injustice and fighting battles at the policy and political levels. The founders of the Army, William and Catherine Booth, began work in Victorian England and took on a range of 'social evils' - from poverty and the unregulated sale of alcohol, through to child and domestic abuse, poor industrial and housing conditions, and unemployment. William Booth's treatise In darkest England and the way out (Booth, 1890) was a sharp critique of the worst effects of unbounded industrialisation on the poor and of structural ways that poverty could be addressed.

My own sense of vocation as a social worker was firmly rooted in this soil, and continues to be nourished by ideas and groups that share an affinity with the spirit of the Army. While stationed in Ashburton from 1970 to 1973 my father became a voluntary child welfare officer alongside his Army duties. I remember at age 17 knowing that I wanted to spend my life working with people and working for change, but not being sure how this was going to happen. Straight after secondary school at Mairehau High I started a job with the Community Volunteers organisation, contracted to the St Albans Residents Association in Christchurch, and knew that I was on the right path. Fortunately a wise colleague at that time pointed me in the direction of Canterbury University and the Sociology 101 course. This became the most interesting material I had ever studied up to that point and I soon found my way to the field of social work with the programme at Massey University, Palmerston North. 
I still recall my first introduction to our national social workers professional body. It was around 1983 and I was in the final year of study on the Bachelor of Social Work. Two guest presenters arrived who practised at a local alcohol and drug agency. They talked about the ANZASW and the importance of social workers as a group being active and working for change. It was probably one of those warm afternoons where students tend to 'zone out' - there was minimal discussion at the time. Various staff on the programme were active ANZASW members and many continued to work at national and international levels - a great example for students. Little did I know then that the professional body and the cause to advance the social work profession were going to feature strongly in my career.

\section{A job at the 'Welfare'}

I began employment as a social worker at the Palmerston North office of the Department of Social Welfare in 1984 and became engaged with an active group of colleagues where policy advice for Head Office in Wellington was seen as a responsibility and featured as a regular agenda item for the staff meeting. Some of my colleagues were also members of ANZASW. I soon found myself signed up as a member and became part of the local Manawatu branch and its executive. I recall being in charge of the cheque book with the office of Treasurer; just as well there were only a few financial transactions each year. The foundation was laid and I was hooked. It was stimulating being with colleagues at a time when the profession was active on a range of fronts.

The socio-political environment of the time was full of ferment, including the Springbok rugby tour protests of 1981. The new Lange-led Labour Government arrived in 1984 and initiated a period of major economic and social change. This period was to be subsequently criticised for its effect of increasing inequality within Aotearoa NZ (Kelsey, 1997). However, two changes had a major impact on social work and the social sector. I remember going to hui in 1985 associated with the Ministerial Advisory Committee on a Maori Perspective for the Department of Social Welfare led by John Rangihau. This resulted in the stunning report Puao-te-ata-tu (Ministerial Advisory Committee on a Maori Perspective for the Department of Social Welfare, 1988) that addressed institutional racism and proposed indigenous approaches to working with Maori. It is also important to note other key developments of the time, including the Human Rights Commission enquiry into the residential care of children and the report on institutional racism within the Department of Social Welfare (Beddoe \& Randall, 1994).

Puao-te-ata-tu in turn informed the development of the new Act under which child welfare would operate. I recall some of the work done by social workers informing that development and my own experience of working under the new Children, Young Persons and Their Families Act 1989. It was a pleasure to work with the new Family Group Conference processes for both child protection and youth justice, which had been established in the Act (Nash \& Miller, 2013).

\section{ANZASW and competency assessment}

Mary Nash notes the dates of 1973-1986, during which I began my practice, and calls it, 'a period of consolidation' for the profession. The subsequent period of 1987-2002, when I was 
active in national roles, captured the challenge of 'who defines professional social work?' (Nash \& Miller, 2013, pp. 333-334).

I was at the national AGM in 1988 where, due to the membership numbers having dropped, there was serious consideration to wind up ANZASW. Fortunately, Merv Hancock took the initiative and proposed a competency assessment programme which would be a version of self-regulation for the profession (Nash \& Miller, 2013, p. 334). After undertaking my own competency assessment in Hamilton, I later became the national assessor for the Waikato-Bay of Plenty region and, some years after that, the national assessor for Auckland. This work became part of my portfolio of self-employment at the time, another change in practice which I maintained alongside half-time salaried work. Maurice McGregor made a sterling job of being the inaugural Chair of the Board of Competency (Beddoe \& Randall, 1994).

It was a pleasure to coordinate this profession-led initiative, where practitioners could engage in a peer review of their practice against national profession-based standards. My experience of this process was that many practitioners valued reviewing their practice and receiving appropriate affirmation and encouragement to further develop. This was the expression of self-regulation that was an alternative to the state regulation of many other professions.

The competency programme absorbed a lot of time and money from members and their employers as it was a self-funding arrangement for the profession. There was a fee for undertaking the assessment and many volunteer hours were required for panellists who sat alongside the paid national assessor. The downside of such an internal focus for the Association was more limited attention to public issues and advocacy.

Maori panellists were in high demand to either join the general panels or to sit on specialist Tangata Whenua panels that were developed in the early 1990s (Beddoe \& Randall, 1994). This continued the message from Puao-te-ata-tu (1988) for a stronger Maori voice in groups that had an impact on Maori consumers and the development of processes that were culturally safe for Maori.

\section{National executive}

At the Dunedin conference in 1992 I became the secretary on the national executive and began to gain a much broader appreciation of the profession and of the challenges faced by a diverse membership-based organisation. However, life was much simpler then, with the secretariat consisting of Liz Beddoe working from home and some of the national executive meetings taking place at the kitchen table! The secretariat would grow until a full-time executive officer, Howard Randall, was hired while I was President. Administrative staff were also hired and the first ANZASW office was established in Dunedin. The office subsequently shifted to Christchurch where it now stands. I became national Vice President and President Elect in 1995 and then went on to become President from 1996-1998 with an 'Immediate Past President' stint that followed.

The national council grew during my time on the national executive as we pursued a structural bicultural partnership. Roopu had developed for Tangata Whenua members 
alongside the branches which remained open to all members. Each branch and Roopu became entitled to representation at the national council, which tested our finances and our ability to find meeting processes that would support this partnership. The relationship between the President and the Tangata Whenua leader was critical. The collective of Roopu members had become a large group that began to meet independently to develop a Tangata Whenua voice within ANZASW.

Long after I left national work with ANZASW, it developed a Board structure. No doubt this was a cheaper option and one that tightened up governance processes. But perhaps it lost the sense of broad representation, participation and debate from the earlier structure.

\section{The international arena}

The social work profession in Aotearoa NZ has a good history of involvement with international social work.. Fiona Robertson has had an extensive role as treasurer on the International Federation of Social Workers (IFSW) up to the present, while Buster Curson was previously on the executive committee. Currently, Rory Truell is the secretary general of IFSW. Gavin Rennie was treasurer for the International Association of Schools of Social Work (IASSW) with Angela Barretta-Herman on the board of directors (now in the USA), whereas Mark Henrickson is currently on the board of directors of IASSW. Others have been involved at the regional level. All are Kiwis.

My first taste of the international social work arena was attending the IFSW conference in Colombo, Sri Lanka in 1994. It was a culture shock to visit a developing country that was in the grip of a civil war. The military check points at the airport and along the roads to the city were a clear reminder that I had left behind a much more peaceful land.

I was an observer at the IFSW general meeting, alongside the ANZASW delegation, and gained a better appreciation of the global reach of the profession and of the passionate social workers who represented this diverse group. Many of those international social work colleagues would continue to feature at future meetings and conferences, strengthening the bonds between Aotearoa NZ and the global social work community.

The pattern of holding the IFSW general meeting and international conference at the same time meant I could also offer my first international presentation in Sri Lanka - on the competency assessment programme.

The Asia Pacific regional social work conference in 1995 in Christchurch was a taste of social work in Oceania. It put Aotearoa NZ more firmly on the world stage, and included the visit of the international President of IFSW, Elis Envall. In 2009 the Asia Pacific regional social work conference was held in Auckland.

\section{Te Tiriti o Waitangi and bicultural practice}

Beddoe and Randal (1994) note that the Association began its life in a colonial context and it wasn't until 1986 that its own Standing Committee on Racism presented its challenge and proposed a new Bicultural Code of Practice for members. 
ANZASW enshrined its commitment to honouring Te Tiriti of Waitangi in its 10 Standards of Competency and its Code of Ethics and Code of Bicultural Practice. This was in the context of challenges of racism by Maori and from various reports as mentioned above.

Partnership was a key theme and this became expressed at the national executive through the work of my predecessor Buster Curson when as President, he and Turoa Haronga, as Tangata Whenua leader, developed a strong partnership.

It was my privilege to carry on this practice and become partners with Nora Merle Davis in her role as Tangata Whenua leader. We were able to present a joint leadership expression of the ANZASW bicultural partnership at the 1998 IFSW general meeting and conference in Jerusalem, Israel.

The national council of ANZASW also grew. Roopu had developed as a parallel grouping alongside some branches where Tangata Whenua members could meet. Roopu were increasingly represented at the national council during the 1990s. While we never quite seemed to have the finances to cover this goal, it did not stop the move toward this more comprehensive structural expression of the Association's commitment to honouring Te Tiriti o Waitangi.

Other expressions of tino rangatiratanga for Tangata Whenua social workers included their own national hui, developing Te Komako editions of the Association's journal which were comprised of articles by Tangata Whenua, and the practice of encouraging alternating presidency between Tangata Whenua and Tau Iwi with shared representation on the national executive. The advent of the Tangata Whenua Social Workers Association could be seen as the logical extension of these developments.

ANZASW argued for the inclusion of a commitment to Te Tiriti o Waitangi in the Social Workers Registration Board (SWRB) legislation, but this was denied. However the policies of the SWRB have largely followed through on the bicultural foundation laid by ANZASW.

\section{The long road to registration}

Many debates had been held within ANZASW about registration that included a theme of ambivalence (Nash \& Miller, 2013), but a more formal commitment to explore this occurred in 1994 with the report from the Registration Working Party that had been set up the year before (Blagdon, Taylor, \& Keall, 1994). While President, I spoke at the social work educators Australia and NZ conference in favour of considering statutory registration for our profession (McNabb, 1997). The arguments I made represented those of many members of the time, and followed through to the submissions made to Parliament. Among these were the value of a competency-based approach to registration that continued the commitment of ANZASW to honouring Te Tiriti and bicultural practice. Public accountability was a key argument backed up by a complaints process.

While President, Buster Curson led some of the early work on developing social worker registration, which I was able to pick up on as President and then others including Robyn Corrigan finally led the process through to its installation into law in 2003. This was a significant project for ANZASW which spread onto a much wider canvas when political and government involvement was required. 
The first social workers became registered in 2004. While a majority of members were in favour of registration, it was by no means universally approved. It demanded money which was scarce. The focus on the registration project left other work not done and this was exacerbated once the new Registration Board got to work. Consultation by the Board took members' time and then the process of becoming registered was another significant investment by practitioners and their organisations.

As a member of ANZASW during this period it did seem that the SWRB had pushed the professional body to one side. It felt awkward at times when members of the Board continued their involvement in ANZASW, with dual roles as members of both groups. The Board made decisions within its own meetings, while ANZASW remained open to members about its decision making and could be held to account at its national meetings and AGM, with full knowledge of the SWRB. I believe this made it harder for ANZASW to adjust to having a new regulator and to clarifying its role in what had become quite a different environment for the social work sector. It made it harder for ANZASW to consider its position and make any challenges to the Board (O'Donoghue, 2013b).

The energy of members that went into becoming registered, and adjusting to this new group in the social work sector, meant there was less focus on ANZASW. It was a significant demand on social workers and organisations to manage the setting up of internal processes and resourcing to aid the registration of social work employees.

The advent of registration has been a 'game changer' for the social work sector in Aotearoa NZ. It ushered in a new era in the history of the profession (Nash \& Miller, 2013) and set up a new dynamic which replaced ANZASW as the more influential group on the profession.

I became the Professional Leader of Social Work for the Mental Health Services of the Auckland District Health Board (ADHB) in 1999 through to 2009. My role shifted from one of supporting the establishment of registration to one of ensuring it was implemented as a matter of good clinical governance. This was aided by being in an environment where most other professions were already registered. The challenge came to support social workers who were also active ANZASW members. This was a similar story to that of MidCentral Health (Henderson \& Fry, 2013). The registration of social workers at ADHB was aided by having a Director of Allied Health who oversighted social workers and was part of the senior clinical governance team (Mueller \& Neads, 2005).

\section{Social work education programme approval}

I was part of a group of ANZASW members that thought the profession should have a stronger voice in social work education through a programme approval system. At the time we expected the SWRB to have a role in recognising social work programmes and wanted the professional body to be an active participant.

A Course Approval Board was established within ANZASW in 2002 and developed its own standards which mirrored the 10 Standards of Practice used in the competency assessment of members. Three programme providers were subsequently visited: the University of Otago (2002), the Unitec Institute of Technology (2004) and the University of Auckland (2004). All three providers were awarded a professional programme approval by ANZASW. 
Our hope was that the momentum of the ANZASW course approval system could be linked with the programme recognition role of the SWRB. I recall discussions about collaboration on social work programme recognition with SWRB representatives, held by the national executive and me while we were all at the international IFSW social work conference in Munich, Germany in 2006. Regrettably they never eventuated in any formal arrangements between the two organisations.

Rose Henderson who was President during this time confirms that it remained a mystery as to why the SWRB couldn't find its way to collaborate with ANZASW over programme approval and, with the support of social work educators, institute a truly cross-sector professional recognition for social work programmes (O’Donoghue, 2013b, p. 64).

\section{Social work education}

For the last four years I have been an educator at the Unitec Institute of Technology in the Department of Social Practice, initially in a Head of Department role and now as a lecturer. More recently I have become President of the Council for Social Work Education Aotearoa NZ (CSWEANZ). Gavin Rennie is a former President of this group and a current colleague at Unitec. He notes the long tradition of activity by social work educators in the professional life of our country and at particular periods such as during the development and implementation of social worker registration (Rennie, 2013).

The SWRB undertook a review of its Act in 2011 with CSWEANZ and ANZASW among other groups making submissions where $95 \%$ of submitters affirmed mandatory registration as a change that should be implemented (Social Workers Registration Board, 2012). Although the prime focus of the review was on mandatory registration, the SWRB also noted some concerns about the preparedness of some graduates from some recognised programmes in a letter to the NZ Qualifications Authority. These came from the Children's Commissioner, some health social workers, and Child, Youth and Family (Social Workers Registration Board, 2011).

The SWRB undertook a review of the programme recognition standards during 20112012 which led to a proposal for a four-year, 480 credit-minimum social work programme which has now become policy (Social Workers Registration Board, 2013). Nine of the major providers of programmes with three-year, 360 credit programmes fought this initiative, challenging the lack of evidence that required a change. There were fears that there would be a drop off in students from traditionally marginalised groups such as Maori, Pacific, refugee and migrant, and poorer sectors with no consideration of other ways of enhancing competent practice such as through a supported first year of employment or internship schemes as used by other professions (K. Giles, personal communication, 27 September 2012).

The point has been made that most in our social work sector still hold that registration has been welcomed and deserves its place. However, questions remain about how it has been implemented both from an operational perspective and also regarding the lack of government commitment for the recommendation of the SWRB to have mandatory registration (O’Donoghue, 2013a). 


\section{Social work alliance}

While there have been many tensions arising from the emergence of the SWRB as a new and dominant group in the social work sector, there have been opportunities for collaboration and development. One of the developments in the relationship between the major parties in the social work sector has been the creation of the Alliance group. This is made up of representatives from the SWRB, ANZASW, CSWEANZ and the Tangata Whenua Social Workers Association (TWSWA). The group is relatively new but has developed into a useful forum to discuss issues of mutual concern. The Alliance is also looking to engage with other groups in the social and health sectors to advance the social work profession.

More recently there has been consideration of undertaking joint activity where appropriate. This was illustrated by a press statement supporting the Salvation Army's State of the Nation report, issued by three of the Alliance parties (ANZASW, CSWEANZ \& TWSWA, 2014). While the SWRB is constrained in the range of comment it can make due to being a Crown entity, the other parties are committed to being effective advocates in the public sphere.

Many within our profession yearn for stronger political agency, but a number of us struggle to keep our heads above water managing our operational and practice responsibilities. My previous lecturer and thesis supervisor, Mike $\mathrm{O}^{\prime}$ Brien, is correct in pointing the social work profession back to the fundamental social justice issue of poverty in our society (O'Brien, 2013). The social work sector would do well to sharpen its focus on poverty with our available resources.

Another possibility is jointly hosting continuing professional development activities. Having had a conference run by the SWRB in 2013, and with the 50th anniversary ANZASW conference in 2014, the way may be clear to host a joint conference for the wider social services sector. This type of collaboration has been well demonstrated by the international social work and social development groups with the Social Work, Education and Social Development conference in Melbourne 2014 jointly hosted by IFSW, IASSW and the International Council on Social Welfare (ICSW).

\section{And into the future}

Harms and Connolly note a range of factors that has influenced our profession across the Tasman: the influence of context, the importance of culturally responsive practice, a commitment to social justice and human rights, the challenge of articulating a professional identity and a commitment to lifelong learning (Harms \& Connolly, 2013). These factors are likely to continue to feature in the future of ANZASW and the wider social work sector.

ANZASW has always operated from a broad-based and inclusive approach to membership. I believe the direction of ANZASW to incorporate workers in the social care workforce as a special membership grouping is not only a practical way to remain a viable organisation, but also a way to grow its mandate to engage in the public sphere.

Members have recently engaged in an active debate about social workers and unionisation and covered a range of workplace issues that affect practitioners and their practice 
(ANZASW, 2014). This highlights the importance of the employment context for most social workers and the benefits of having social workers who take up union roles. I think occupational stress and the effects of organisational change have been underplayed in social work and it would therefore be a fertile area for ANZASW to explore with members. It is pleasing to see an emerging literature base on this area (van Heugten, 2013). We also need a strong relationship with employers, the Government and other major groups in our sector.

We need a workforce strategy for social work. The health sector has a sophisticated workforce strategy due to its size and complexity, and due to having high-status professions such as medicine where the timelines for educating and developing practitioners is long and expensive. Health Workforce New Zealand (HWNZ) was set up in 2009 to provide national leadership on the development of the country's health and disability workforce (Ministry of Health, 2014). ANZASW should be an active partner in pursuing a workforce strategy alongside other stakeholders in the social work sector.

We also need a research strategy that will serve our profession. At present research is undertaken on an ad hoc basis according to resourcing and individual interest. CSWEANZ has explored this idea but no firm plans are in place. If we wish to have evidence-informed practice and a strong knowledge base for our profession then research in social work will need a boost (Campbell \& Fouché, 2013). There are a small group of academics doing most of the research and publishing. A concerted effort by many parties in our sector is required to improve the future of research in social work.

ANZASW should not deviate from its well established commitment to Te Tiriti o Waitangi and to strengthening Tangata Whenua social work and practice with Maori. It should further develop the stream of Pasifika social work, expressed in the Pasifika Social Workers Interest Group and in Tu Mau, the Pasifika editions of the journal. The development of social work with people from refugee and migrant backgrounds begs further attention as this population grows and as the demands for refugee and migrant-background social workers increases. We should continue to focus on ensuring more effective cross-cultural practice generally (Maidment, 2013).

\section{Social work reform?}

ANZASW's 50th birthday is a little like the middle adulthood period theorised by Erikson as the challenge of generativity vs stagnation (Erikson \& Erikson, 1998). It is timely to review our stage of development.

I wonder if we would benefit from a Kiwi version of the social work sector review and subsequent reform of social work in England that led to the establishment of The College of Social Work in 2012? There seem to be a lot of positives for the profession. It was pleasing to hear Dame Moira Gibb present on her work leading first the Social Work Task Force then the Social Work Reform Board, at the Social Workers Registration Board conference in November 2013. The mission statement of the College is that:

...[the College] enables the development of the profession, responding to current and future challenges, in turn benefitting the people the profession exists to serve. It acts as the public voice of social work, representing social work and social workers in the media, with government and with employers (The College of Social Work, 2014). 
It has developed a Professional Capabilities Framework to guide practice and education, the Assisted First Year of Employment, standards for employers and supervision, leadership tools and continuing professional development advice. It is a voice for social work in the policy and public spheres, and provides a range of resources for social work education and fieldwork. The reforms have required a huge level of resourcing and government support over several years. I would be sceptical of anything like this happening for social work in Aotearoa NZ due to the resourcing, consensus across our sector and political will required. However, it is a development well worth considering.

\section{Conclusion}

The social work sector is made up of many interest groups and a range of relationships, all subject to powerful external forces including the Government and the global economy. A number of those forces can have a negative impact. However, at the heart of the social work profession, like any other profession, are a core group of colleagues engaged in practice and committed to a mission of individual and societal transformation. The greatest strength lies in the collective that is constituted by the practitioners. The professional body is the one thing those practitioners can control and so it should be treasured by its members, as evidenced by historical achievements. Collaborations with others will be critical for future developments in our sector as we have limited energy and resources.

Twenty years ago Merv Hancock, the first President of ANZASW, responded in an interview to a question about the future of social work. I think these words continue to hold true:

The future holds as much uncertainty as the past. It is very important to live with uncertainty and to accept it. The uncertainty of the world economy is always present, and anybody who suggests that it is not uncertain is a rogue and a vagabond. However, although uncertainty is the order of the day, the future is in a sense what one makes of it. Social work can make a contribution to defining the kind of society we live in. Therefore it needs to maintain a level of optimism about itself (Munford \& Nash, 1994, p. 13).

I salute my professional elders who launched ANZASW in 1964 and the many colleagues who have led and been active in the life of the profession since. My own 30 years or so of membership have been more rewarding than I could ever have imagined at the beginning. The advent of social work registration has been a 'game changer' for our profession. And, we must continue to have a clear profession-based influence on the future of registration. We should rechart the course for ANZASW using our hard-won wisdom. ANZASW has a fine record of achievement for its first 50 years and should embrace its next 50 .

\section{References}

ANZASW. (2014). Noticeboard Kete. 15. Retrieved from http://www.blacksheepcreative.co.nz/fanmail/action/ view / ?link=cJPFo8WamHKX18iUZ5XC15mXmmppwpyTkWNnl5KRm3Cb.

ANZASW, CSWEANZ, \& TWSWA. (2014, 17 February). Salvation Army report fully endorsed. Retrieved from http: / / www.scoop.co.nz/stories / PO1402/S00180/ salvation-army-report-fully-endorsed.htm.

Beddoe, E., \& Randall, H. (1994). The New Zealand Association of Social Workers: The professional response to a decade of change. In R. Munford \& M. Nash (Eds.), Social work in action (pp. 21-36). Palmerston North, NZ: Dunmore Press.

Blagdon, J., Taylor, M., \& Keall, B. (1994). Social worker registration. Social Work Review, 6(4), 24-25.

Booth, W. (1890). In darkest England and the way out. London: The Salvation Army. 
Campbell, L., \& Fouché, C. (2013). Research in social work. In M. Connolly \& L. Harms (Eds.), Social work: Contexts and practice (3rd ed., pp. 356-370). Melbourne: Oxford University Press.

Erikson, E. H., \& Erikson, J. M. (1998). The life cycle completed. New York: W. W. Norton.

Harms, L., \& Connolly, M. (2013). Trans-Tasman reflections. In M. Connolly \& L. Harms (Eds), Social work: Contexts and practice (pp. 408-412). Melbourne: Oxford University Press.

Henderson, E., \& Fry, K. (2013). Implementing registration within a health organisation setting. Aotearoa New Zealand Social Work Review, 25(3), 11-18.

Kelsey, J. (1997). The New Zealand experiment: A world model for structural adjustment? Auckland, NZ: Auckland University Press.

Maidment, J. (2013). Cross-cultural practice. In M. Connolly \& L. Harms (Eds), Social work: Contexts and practice (pp. 163-176). Melbourne: Oxford University Press.

McNabb, D. (1997). Registration for New Zealand social workers? Social Work Review, 9(4), 43-45.

Ministerial Advisory Committee on a Maori Perspective for the Department of Social Welfare. (1988). Puao-te-atatu (daybreak): The report of the Ministerial Advisory Committee on a Maori perspective for the Department of Social Welfare. Wellington, N.Z.: Department of Social Welfare.

Ministry of Health. (2014). Health Workforce New Zealand. Retrieved from http: / / www.healthworkforce.govt.nz/ about-us.

Mueller, J., \& Neads, P. (2005). Allied health and organisational structure: Massaging the organisation to facilitate outcomes. New Zealand Journal of Physiotherapy, 33(2), 48-54.

Munford, R., \& Nash, M. (1994). Preface: A conversation with Mervyn Hancock. In R. Munford \& M. Nash (Eds), Social work in action (pp. 9-14). Palmerston North, NZ: Dunmore Press.

Nash, M., \& Miller, J. (2013). Social work: Where we have been and where we are going. In M. Connolly \& L. Harms (Eds), Social work: Contexts and practice (pp. 329-345). Melbourne: Oxford University Press.

O'Brien, M. (2013). Social work registration and professionalism: Social justice and poverty - fellow travellers or discarded passengers? Aotearoa New Zealand Social Work Review, 25(3), 50-59.

O'Donoghue, K. (2013a). Editorial: The Social Workers Registration Act (2003) - 10 years on. Aotearoa New Zealand Social Work Review, 25(3), 1-2.

O'Donoghue, K. (2013b). A former President reflects on the effects of social worker registration upon the Association: An interview with Rose Henderson. Aotearoa New Zealand Social Work Review, 25(3), 60-67.

Rennie, G. (2013). Registration ten years on: A perspective from a social work educator. Aotearoa New Zealand Social Work Review, 25(3), 3-10.

Social Workers Registration Board (2011, 6.12.11). [Social Workers Registration Board recognition of social work programmes].

Social Workers Registration Board. (2012). Social Workers Registration Act (2003) review report October 2012. Retrieved from file: / / / : / Users / Pam / Downloads / 2012\%20Review\%20of\%20SWR \%20Act\%202003.pdf.

Social Workers Registration Board. (2013). The process of recognition and re-recognition of social work qualifications in NZ. Retrieved from file: / / C: / Users / Pam/Downloads/Programme $\% 20$ recognition $\% 20$ standards $\% 20-\% 20$ 2013.pdf.

The College of Social Work. (2014). The college of social work. Retrieved from http: / www.tcsw.org.uk/ resources / reform-resources/.

Van Heugten, K. (2013). Thriving at work: Preventing occupational stress. In M. Connolly \& L. Harms (Eds), Social work: Contexts and practice (pp. 396-407). Melbourne: Oxford University Press. 